\title{
Immunoblotting in the diagnosis of culture negative endocarditis caused by streptococci and enterococci
}

\author{
J P Burnie, I Clark
}

\begin{abstract}
Aim-To improve the diagnosis of culture negative endocarditis by diagnosing cases due to streptococci and enterococci. Method-Serum samples were immunoblotted against extracts of the commonest streptococci and enterococci. They were selected from patients with a cardiac murmur, persistent pyrexia and at least three negative blood cultures. The presence of patterns of endocarditis species specific antigenic bands was measured and correlated with clinical outcome.

Results-Negative serology was found in 28 patients where the diagnosis of endocarditis was rejected or, if proved, staphylococcal, yeast, Gram negative, systemic lupus erythematosus, due to $\mathbf{Q}$ fever or Chlamydia psittaci or nonbacterial thrombotic. Positive serology was found in 27 of the 34 patients where the response to antibiotics suggested streptococcal or enterococcal infection. In 22 of these there was objective evidence of endocarditis. Positive serology was also found in three of four further patients with vegetations at necropsy.

Conclusion-The identification of patterns of antibody response on immunoblotting can be used to make a specific diagnosis of streptococcal or enterococcal endocarditis in the absence of positive blood cultures.

(f Clin Pathol 1995;48:1130-1136)
\end{abstract}

Keywords: Immunoblotting, culture negative endocarditis, serodiagnosis.

Prior to the development of antibiotics, infective endocarditis was universally fatal with patients dying within a few months of diagnosis. ${ }^{1}$ The advent of antibiotics and valve replacement surgery along with our ability to isolate the specific micro-organism by blood culture has led to a reduction in mortality to between 14 and $46 \% .{ }^{2}$ However, there remain patients with active endocarditis where repeated blood cultures are negative. The incidence ranges from 2.5 to $31 \% .^{3}$ One important cause is the prior administration of antibiotics. This reduced the incidence of positive blood cultures in patients with documented streptococcal endocarditis ${ }^{4}$ and was more likely to have occurred in patients with culture negative rather than culture positive endocarditis. ${ }^{56}$ Exclusion of these cases and the handling of blood cultures in an experienced laboratory has led to a revised incidence of culture negative endocarditis of approximately $5 \%{ }^{7}$

The diagnosis of culture positive endocarditis has been confirmed by a variety of serological techniques measuring antibody. These have either demonstrated a raised total antibody as with immunofluorescence, ${ }^{89}$ indirect enzyme linked immunosorbent assay (ELISA) ${ }^{1011}$ and counterimmunoelectrophoresis ${ }^{12}$ or characterised individual patterns of antigenic bands by immunoblotting. ${ }^{13-15}$ The latter is species specific for Enterococcus faecalis, Enterococcus faecium, Streptococcus mutans, Streptococcus bovis, Streptococcus pneumoniae, Streptococcus agalactiae, Streptococcus sanguis, and Streptococcus lactis. ${ }^{115}$ This presents the possibility of detecting the same patterns of antibody reactivity in the serum of patients with culture negative endocarditis (CNE). This would lead to a more precise laboratory diagnosis and the initiation of: appropriate antibiotic therapy or the continued search for another cause of the pyrexia.

The definitive diagnosis of endocarditis is dependent on the demonstration of vegetations on a heart valve at surgery or necropsy or a peripheral embolus. ${ }^{7}$ Recently, a secondary set of clinical criteria has been developed. ${ }^{16}$ This consists of major criteria (positive echocardiogram and typical blood culture) and minor criteria (predisposition, fever, vascular phenomena, immunological phenomena, suggestive echocardiogram, and suggestive microbiology). There are also patients with a fever, cardiac murmur and negative blood cultures in whom the diagnosis of $\mathrm{CNE}$ is queried by clinicians. This can occur in the absence of objective clinical signs of endocarditis and a negative echocardiogram.

We examined serum samples from such patients as well as those who have objective evidence of vegetations, demonstrated by a peripheral embolus, a positive echocardiogram, surgical excision, or necropsy. They were immunoblotted against extracts of streptococci and enterococci to test for the species specific, endocarditis specific antigenic bands listed in table 1. These were derived from previous work. ${ }^{141517}$ The entry requirements for the present study were persistent pyrexia of greater than $38^{\circ} \mathrm{C}$ for at least five days, a cardiac murmur and a minimum of at least three negative blood cultures. The patients were then subdivided according to their final clinical diagnosis. This took into account evidence of vegetations such as positive echocardiograms, 
Table 1 Species specific antigenic bands to which the presence of antibody was considered to be diagnostic of endocarditis

\begin{tabular}{|c|c|c|c|}
\hline Bacteria & & Antibody class & $\begin{array}{l}\text { Apparent molecular } \\
\text { weight }(k D a) \text { (no. of bands) }\end{array}$ \\
\hline $\begin{array}{l}E \text { faecalis } \\
E \text { faecium } \\
S \text { bovis } \\
S \text { sobrinus } \\
S \text { agalactiae }\end{array}$ & $\begin{array}{l}\text { NCTC } 755 \\
\text { NCTC } 7171 \\
\text { NCTC } 8183 \\
\text { MUCOB } 263 \\
\text { MUCOB } 204\end{array}$ & $\begin{array}{l}\text { IgM/IgG } \\
\text { IgM/IgG } \\
\text { IgM/IgG } \\
\text { IgM/IgG } \\
\text { IgM }\end{array}$ & $\begin{array}{l}88-90,45-47 \\
82-90 \text { ( } 3 \text { bands) } \\
70-140 \text { ( } \geqslant 5 \text { bands) } \\
220,200,190 \\
82,71,66-67\end{array}$ \\
\hline$S$ pneumoniae & Clinical isolate & $\begin{array}{l}\text { IgG } \\
\text { IgM/IgG } \\
\text { IgM }\end{array}$ & $\begin{array}{l}34-36,31-33,30 \\
150-190(\geqslant 4 \text { bands }) \\
123,100,90\end{array}$ \\
\hline $\begin{array}{l}S \text { gordonii } \\
S \text { oralis }\end{array}$ & $\begin{array}{l}\text { F90A/NCTC } 7868 \\
\text { NCTC } 7864\end{array}$ & $\begin{array}{l}\mathrm{IgM} / \mathrm{IgG} \\
\mathrm{IgM} / \mathrm{IgG}\end{array}$ & $\begin{array}{l}180,80-82,45 \\
180,80-82\end{array}$ \\
\hline
\end{tabular}

vegetations seen at necropsy or surgery, response to empirical antibiotic therapy or a final diagnosis such as lupus non-bacterial verrucous endocarditis or one of the conditions associated with non-bacterial thrombotic endocarditis. ${ }^{18}$ This study thus assessed the use of immunoblotting (where this was consistent with the clinical progress of the patient) in the diagnosis of streptococcal or enterococcal endocarditis in the absence of positive blood cultures.

\section{Methods}

CLINICAL SAMPLES

Serum samples were collected from patients referred with possible CNE. They all had a history of at least three negative blood cultures, a persistent murmur and a pyrexia of $38^{\circ} \mathrm{C}$ or greater for at least five days.

The patients were subdivided as follows: group 1 , no objective evidence of vegetations (table 2). Group 1A patients were treated empirically and successfully for streptococcal or enterococcal endocarditis by two weeks of intravenous penicillin or amoxycillin plus an aminoglycoside followed by four weeks of oral chemotherapy. In group 1B patients the diagnosis of endocarditis was subsequently rejected. Group 2, evidence of vegetations as shown by a positive echocardiogram. Some cases had suggestive immunological and vascular phe- nomena and in others the vegetations were demonstrated at surgery. The patients were treated successfully for either streptococcal or enterococcal endocarditis (group 2A; table 3), staphylococcal (group 2B), yeast (group 2C), Gram negative (group 2D) or Q fever, or Chlamydia psittaci (group 2E) endocarditis (table 4). Group 3, vegetations were confirmed at necropsy (table 5). Group 4, diagnosed as having lupus non-bacterial verrucous endocarditis (table 5). All patients had a positive echocardiogram and systemic lupus erythematosus (SLE). Group 5, the patients had one of the conditions associated with non-bacterial thrombotic endocarditis (table 5). There was no evidence of infective endocarditis as judged by a response to empirical antibiotic therapy where this was initiated. Some patients had a positive echocardiogram.

\section{IMMUNOBLOTTING \\ Isolates}

Extracts were prepared from Enterococcus faecalis NCTC 775, Enterococcus faecium NCTC 7171, Streptococcus bovis, type 1, NCTC 8183, Streptococcus sobrinus (Manchester University Collection of Bacteria, MUCOB 263), Streptococcus oralis NCTC 7864, Streptococcus gordonii NCTC 7868, $S$ gordonii F90A, Streptococcus agalactiae (MUCOB 204), and Streptococcus pneumoniae (isolated from a patient with endocarditis ${ }^{15}$ ). $S$ sobrinus (MUCOB 263) was previously referred to as $S$ mutans (MUCOB 263) but is closer in phenotype to $S$ sobrinus. ${ }^{19} S$ gordonii F90A was previously referred to as $S$ sanguis F90A, but has been reclassified. ${ }^{20}$ Isolates were cultured in brain heart infusion broth for 48 hours at $37^{\circ} \mathrm{C}$ in a rotary shaker. Cultures were pelleted by centrifugation at $2500 \times g$ for 15 minutes, resuspended in $10 \mathrm{~mm}$ Tris $/ \mathrm{HCl}(\mathrm{pH} \mathrm{7.5)}$ and repelleted. Fragmentation was performed at $-20^{\circ} \mathrm{C}$ in an $\mathrm{X}$-press. The disintegrated cells were centrifuged at $10000 \times g$ for 10 minutes.

Table 2 Clinical details of patients in groups $1 A$ and $1 B$

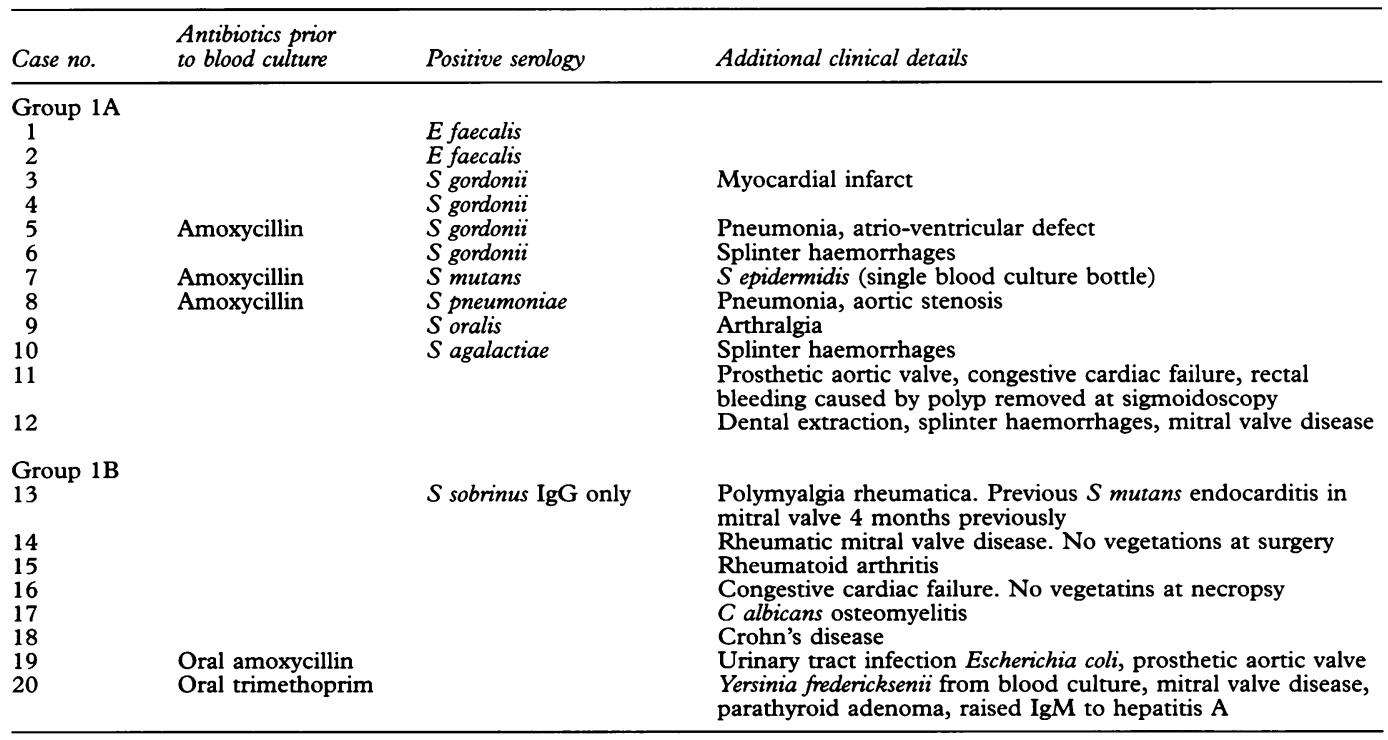


Table 3 Clinical details of patients in group $2 A$

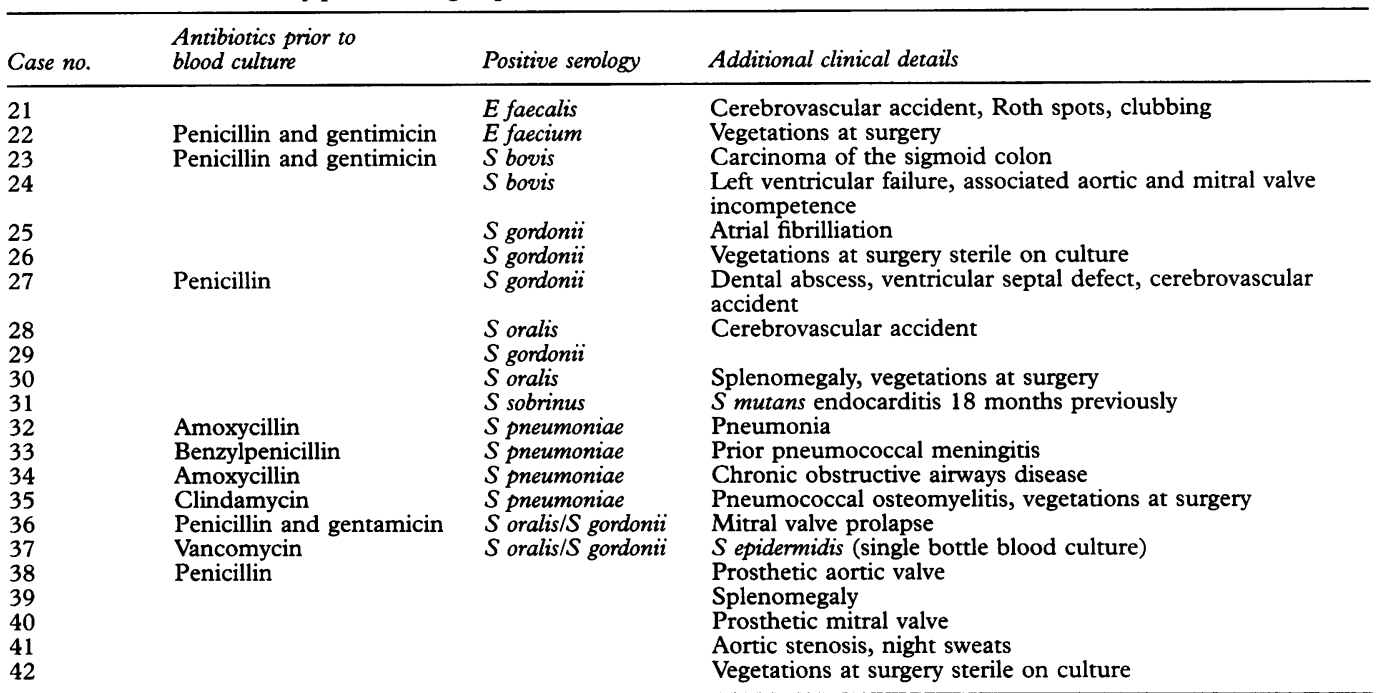

Table 4 Clinical details of patients in groups $2 B$ to $2 E$

\begin{tabular}{|c|c|c|c|}
\hline Case no. & $\begin{array}{l}\text { Antibiotics prior to } \\
\text { blood culture }\end{array}$ & Positive serology & Additional clinical details \\
\hline $\begin{array}{l}\text { Group 2B } \\
43 \\
44 \\
45\end{array}$ & $\begin{array}{l}\text { Penicillin } \\
\text { Vancomycin }\end{array}$ & & $\begin{array}{l}\text { Intravenous line } S \text { epidermidis, responded vancomycin and gentamicin } \\
\text { Intravenous line } S \text { epidermidis, responded vancomycin and gentamicin } \\
\text { Intravenous line } S \text { epidermidis responded flucloxacillin and gentamicin }\end{array}$ \\
\hline $\begin{array}{l}\text { Group 2C } \\
46\end{array}$ & & & $\begin{array}{l}\text { Yeast seen on Gram stain of aortic prosthetic valve obtained at } \\
\text { surgery. Responded to amphotericin B }\end{array}$ \\
\hline $\begin{array}{l}\text { Group 2D } \\
47\end{array}$ & & & $\begin{array}{l}\text { Haemophilus parainfluenzae sputum, endocarditis } 18 \text { years previously, } \\
\text { valve culture negative }\end{array}$ \\
\hline $\begin{array}{l}\text { Group } 2 \mathrm{E} \\
48 \\
49\end{array}$ & & & $\begin{array}{l}\mathrm{Q} \text { fever, complement fixation test positive }(1 \text { in } 1024) \\
C \text { psittaci, complement fixation test positive }(1 \text { in } 512)\end{array}$ \\
\hline
\end{tabular}

Table 5 Clinical details of patients in groups 3, 4 and 5

\begin{tabular}{|c|c|c|c|}
\hline Case no. & $\begin{array}{l}\text { Antibiotics prior to } \\
\text { blood culture }\end{array}$ & Positive serology & Additional clinical details \\
\hline $\begin{array}{l}\text { Group } 3 \\
50 \\
51\end{array}$ & \multirow{2}{*}{$\begin{array}{l}\text { Vancomycin } \\
\text { Flucloxacillin and } \\
\text { fusidic acid } \\
\text { Benzylpenicillin }\end{array}$} & \multirow{2}{*}{$\begin{array}{l}\text { E faecalis } \\
S \text { pneumoniae } \\
S \text { oralis/S gordonii }\end{array}$} & $\begin{array}{l}E \text { faecalis isolated from vegetations at necropsy } \\
\text { Septic arthritis, } S \text { aureus isolated from vegetations at necropsy }\end{array}$ \\
\hline $\begin{array}{l}52 \\
53 \\
54\end{array}$ & & & $\begin{array}{l}\text { Prior } S \text { pneumoniae meningitis, necropsy confirmed sterile vegetations } \\
\text { Necropsy confirmed sterile vegetations } \\
\text { Necropsy confirmed sterile vegetations }\end{array}$ \\
\hline $\begin{array}{l}\text { Group } 4 \\
55^{*} \\
56^{*} \\
57^{*} \\
58^{*}\end{array}$ & & & $\begin{array}{l}\text { SLE } \\
\text { SLE } \\
\text { SLE, mitral incompetence } \\
\text { SLE }\end{array}$ \\
\hline $\begin{array}{l}\text { Group } 5 \\
59 \\
60 \\
61 \\
62 \\
63^{*} \\
64^{*} \\
65\end{array}$ & Cefotaxime and & & $\begin{array}{l}\text { Chronic myeloid leukaemia } \\
\text { Hodgkin's lymphoma } \\
\text { Non-Hodgkin's lymphoma } \\
\text { Lung cancer } \\
\text { Thrombocytopenia, Henoch Schonlein purpura } \\
\text { Rheumatic heart disease, Goodpasteur's syndrome } \\
\text { Adenocarcinoma of the prostate }\end{array}$ \\
\hline 66 & $\begin{array}{l}\text { Vancomycin and } \\
\text { gentamicin }\end{array}$ & & Acute myeloid leukaemia, invasive aspergillosis \\
\hline
\end{tabular}

* positive echocardiogram.

The supernatant was used in further experiments and stored at $-20^{\circ} \mathrm{C}$.

Sodium dodecyl polyacrylamide gel electrophoresis The supernatants were solubilised in $2.6 \%$ sodium dodecyl sulphate and 2-mercapto- ethanol at $100^{\circ} \mathrm{C}$ for five minutes. Electrophoresis of these preparations was carried out on a $10 \%$ polyacrylamide gel in a discontinuous buffer system. Protein $(10 \mu \mathrm{g})$ was applied to each well. Molecular weight standards were the Amersham Rainbow markers. These were myosin 200000 , phos- 
phorylase B92500, bovine serum albumin 69000 , ovalbumin 46000 , carbonic anhydrase 30000 , trypsin inhibitor 21500 , and lysozyme 14300 .

\section{Immunoblots}

Proteins were transferred onto nitrocellulose paper in a buffer containing $25 \mathrm{mM}$ TRIS, $192 \mathrm{mM}$ glycine and $20 \%$ methanol (pH 8.3). Transfer was performed at $25^{\circ} \mathrm{C}$ with a current of 500 milliamps for 30 minutes in a transphor cell (LKB Laboratories). Free protein sites were saturated by incubation in 3\% bovine serum albumin (Sigma, Poole, Dorset, UK) in buffered saline $(0.9 \% \mathrm{NaCl}$ and $10 \mathrm{mM}$ TRIS $(\mathrm{pH} 7 \cdot 4)$ ) at $4^{\circ} \mathrm{C}$ overnight. The nitrocellulose membrane was then incubated at $25^{\circ} \mathrm{C}$ for two hours with each patient's serum diluted 1 in 10 in $3 \%$ bovine serum albumin and $0.5 \%$ Tween 20 in buffered saline. After washing five times for 30 minutes in $0.9 \%$ saline and $0.5 \%$ Tween 20, the nitrocellulose was incubated for one hour at $25^{\circ} \mathrm{C}$ with alkaline phosphatase conjugated anti-human IgM or IgG (Sigma). The conjugate was diluted 1 in 1000 in 3\% bovine serum albumin in buffered saline. After washing as described above, the nitrocellulose was incubated for 15 minutes at $25^{\circ} \mathrm{C}$ with buffer (100 mM TRIS/ $\mathrm{HCl}, \mathrm{pH} 9.5,100 \mathrm{mM}$ $\mathrm{NaC} 1,5 \mathrm{mM} \mathrm{MgC1} 1_{2}$ ) containing a mixture of $66 \mu \mathrm{l} / 10 \mathrm{ml}$ of nitroblue tetrazolium (NBT 50 $\mathrm{mg} / \mathrm{ml}$ in $\mathrm{N}, \mathrm{N}$-dimethylformamide $70 \%$ ) and $33 \mu \mathrm{l} / 10 \mathrm{ml}$ of 5 -bromo-4-chloro-3 indolyl phosphate (BC1P $50 \mathrm{mg} / \mathrm{ml}$ in $\mathrm{N}, \mathrm{N}-\mathrm{di}$ methyformamide $70 \%$ ). The reaction was stopped by washing in water. Immunoblots were semi-quantified by reflectance densitometry (Chromoscan 3; Joyce Loebl) for the bands defined in table 1 . A scan height greater than $40 \mathrm{~mm}$ was counted as positive.

\section{Results}

For the 20 patients in group 1 , where objective evidence of endocarditis was lacking, serum samples from 10 were positive on immunoblotting against $E$ faecalis or a specific streptococcal species. All of these patients responded to antibiotic therapy as expected for streptococcal or enterococcal endocarditis. This was also the case in patients 11 and 12 who did not produce antibody. In the eight cases where the diagnosis of endocarditis was subsequently rejected only patient 13 produced an IgG response against $S$ mutans. This was due to a successfully treated episode of $S$ mutans endocarditis four months previously. All patients in group 2 had confirmed endocarditis and were subdivided according to the spectrum of the antimicrobials used in therapy (groups $2 \mathrm{~A}$ to $2 \mathrm{D}$ ) or positive atypical serology (group 2E). A positive antibody response was detected in cases 21-37 who were managed as either streptococcal or enterococcal endocarditis. In case 23 the high antibody response (fig 1) against $S$ bovis prompted a search for a large bowel neoplasm which was subsequently found in the sigmoid colon. In case 31 immunoblotting suggested a partially treated $S$ mutans endo-

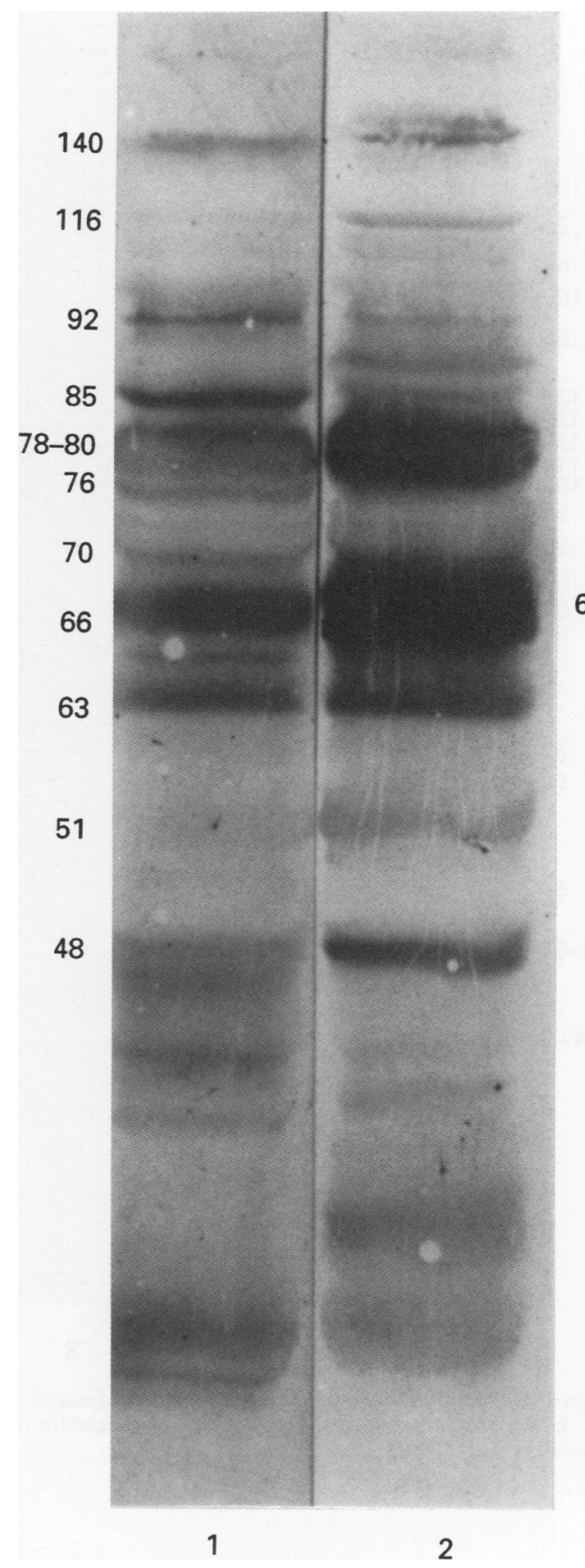

Figure 1 Serum from case 23 assayed for IgM (lane 1) and $\operatorname{IgG}$ (lane 2) directed against $\mathrm{S}$ bovis.

carditis as there was $\operatorname{Ig} M$ directed against bands at 220,200 and 190 . In cases $32-35$ the previous history suggested pneumococcal infection and the serology active $S$ pneumoniae endocarditis. Case 33 had a persistently high IgM antibody titre (fig 2). In cases 36 and 37 the immunoblots for both $S$ oralis and $S$ gordonii were positive, suggesting that some of the immunodominant antigens were shared. In cases 38-42 the negative results did not correlate with clinical outcome. In contrast, the negative serology in cases 43-49 was consistent with staphylococcal (group 2B), yeast (group 2C), Gram negative (group 2D), or atypical (group 2E) endocarditis.

In group 3 patients vegetations were seen at necropsy and their culture in case 50 confirmed $E$ faecalis endocarditis. In case 51 a negative 


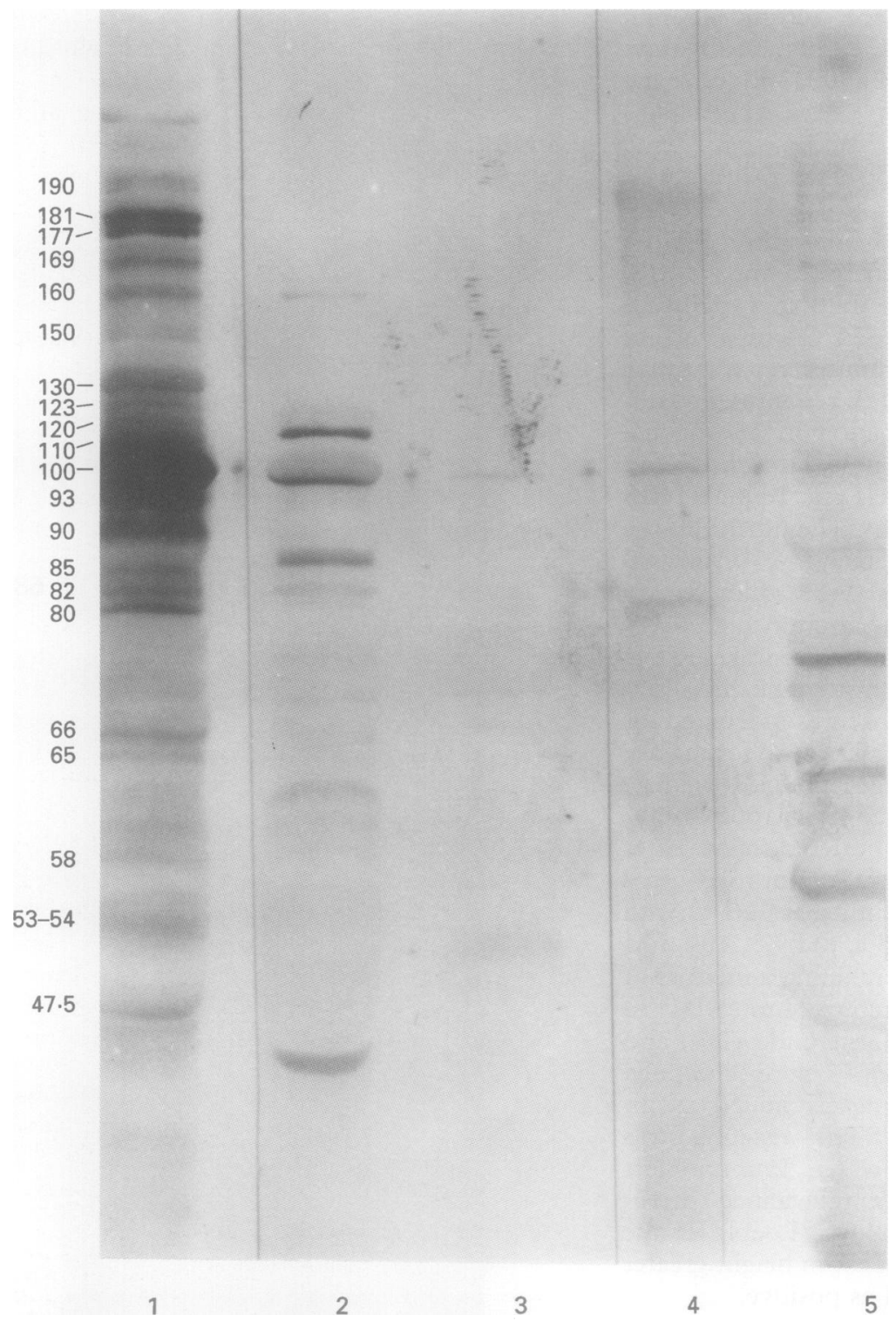

Figure 2 Serum from case 33 assayed for IgM directed against S pneumoniae (lane 1), E faecalis (lane 2), E faecium (lane 3), S gordonii NCTC 7868 (lane 4), and $\mathrm{S}$ oralis NCTC 7864 (lane 5). from group 2A, and by a positive antibody response and isolation of the bacteria at necropsy or causing meningitis prior to the development of endocarditis, cases 50 and 52 from group 3. Case 53 (group 3) has been included as a true positive on the basis of the antibody response. Cases 38-42 from group 2A were antibody negative but responded to treatment for streptococcal or enterococcal endocarditis. These cases have been defined as false negatives with the caveat other bacteria such as those in the HACEK (Haemophilus, Actinobacillus, Cardiobacterium, Eikenella, Kingella) group would have responded to this regimen. ${ }^{21}$

The patients in group 1A failed to fulfil the necessary criteria for a diagnosis of endocarditis ${ }^{716}$ and have been excluded from this analysis. Cases 54 (group 3) has also been omitted. This is due to the lack of response to antimicrobials, the absence of antibody and the sterile culture of vegetations at necropsy making it impossible to define the case as a true or false negative. There were no false positives. Having made the above assumptions, the sensitivity of the test was $85 \%$, the specificity $100 \%$ and efficiency $91 \%$.

\section{Discussion}

Research on the serology of culture positive endocarditis caused by streptococci and enterococci has repeatedly confirmed the high levels of antibody. An immunofluorescence titre equal or greater than 400 when the patient's serum was examined against the corresponding isolate was virtually diagnostic of endocarditis. ${ }^{9}$ An indirect ELISA test for antibodies against the serotype I antigen from nutritional variant streptococci (NVS) was positive in 23 of 31 serum samples from patients with NVS endocarditis. In contrast, only 10 of 30 serum samples from patients with non-NVS streptococcal endocarditis contained antibody. ${ }^{10}$

Crossed immunoelectrophoresis demonstrated a significant association $(p<0.002)$ between the finding of viridans streptococci in the blood and the development of specific precipitins. This did not apply to $S$ aureus endocarditis, but did permit the identification of five of 23 cases of CNE as caused by a viridans streptococcus. ${ }^{12}$

The dissection of the antibody response in endocarditis by immunoblotting was originally applied to cases due to E faecalis. ${ }^{1314}$ This not only confirmed the high level of species specific antibody but introduced the concept that the presence of antibody against specific antigens could distinguish between a bacteraemia and a bacteraemia complicating endocarditis. Individual $E$ faecalis antigens have been cloned, sequenced, expressed, and used as the basis of an indirect ELISA for measuring this specific antibody. ${ }^{223}$

The concept was then applied to other streptococci. ${ }^{15}$ In the case of $S$ mutans one of the antigens has been identified as antigen I/II and its immunodominance confirmed by ELISA in five patients with $S$ mutans endocarditis. ${ }^{11}$ A clone obtained by screening a $\lambda$ ZAP DNA antibody response and a nosis. True positives, as defined by a positive antibody response and response to appropriate antimicrobial therapy, included cases $21-37$ 
library derived from $S$ sobrinus MUCOB 263 with serum from a patient with $S$ mutans endocarditis had, on sequencing, a $99 \cdot 2 \%$ homology to the Spa A antigen of $S$ sobrinus and $68.4 \%$ homology to the antigen $\mathrm{I} / \mathrm{H}$ of $S$ mutans. ${ }^{19}$ In the case of $S$ pneumoniae an immunodominant cell surface protein of approximately 90 kilodaltons, pneumococcal surface protein, has been described. This may be the band presented in table $1 .^{24}$

The identification of the viridans streptococci in a routine clinical laboratory is difficult. For example, only three of 16 identical viridans streptococcal endocarditis isolates sent to five institutions were identified as the same species. ${ }^{25}$ In our original work immunoblotting was carried out against $S$ sanguis F90A. ${ }^{14}$ This was subsequently reclassified as $S$ gordonii F90A. ${ }^{20}$ For the purpose of this study, antibody was measured against this isolate, $S$ gordonii NCTC 7868 and $S$ oralis NCTC 7864 . Antibody against a conserved band at 80-82 kilodaltons was present in all of the isolates when reacted with serum from culture positive cases, regardless of whether the originating laboratory had reported the causative bacteria as $S$ oralis, $S$ gordonii, $S$ sanguis, $S$ mitis, or $S$ mitior. This band reacted with a monoclonal antibody specific to the conserved epitope LKVIRKNIV from candidal heat shock protein (HSP) 90 (Burnie JP, personnel communication). ${ }^{26}$ This suggested that this molecule is a member of the ubiquitous HSP90 group of proteins. The presence of shared antigens explains the lack of species specificity in the antibody response of cases 36, 37 and 53. Antibody was measured against $S$ oralis NCTC 7864 because immunoblotting serum from cases where the causative streptococcus was known to be definitely either $S$ gordonii or $S$ oralis had shown a slightly different pattern. ${ }^{17}$

Burnie et al $^{14}$ examined serum samples from seven possible cases of $\mathrm{CNE}$ and showed that only the two cases where the diagnosis of streptococcal endocarditis was likely produced an antibody response on immunoblotting. The present study extended this to a further 66 patients. Negative serology was observed in the 28 patients where the diagnosis of streptococcal or enterococcal endocarditis was no longer considered valid. Positive serology was a predictor of response to appropriate antimicrobial therapy in cases 1-10 (group 1A) and cases 21-37 (group 2A). The negative serology, despite a response to antibiotic therapy in cases 11 and 12 (group 1A) and cases 38-42 (group 2A), might have been due to either infection by micro-organisms in the HACEK group or NVS where the examination of serum samples by immunoblotting from culture positive patients has been disappointing. ${ }^{15}$ This paper has also delineated a group of patients (cases 1-10, group 1A) with pyrexia, cardiac murmur, negative blood cultures, a positive antibody test, a response to appropriate antimicrobials, and a negative echocardiogram. This should act as a cautionary note against basing the diagnosis of endocarditis solely on echocardiography. ${ }^{16}$
The series also reinforced the significance of antibiotic therapy before taking blood cultures. In the 30 cases where serology suggested either streptococcal or enterococcal endocarditis, prior antibiotic therapy had been given in 14 . This agrees with the findings of other authors. ${ }^{3-6}$ It revealed a series of six patients (cases 8, 32-35 and 52) where the causative agent was thought to be $S$ pneumoniae. This would indicate that infection of the heart valve was present during the original illness. Its subacute nature and the administration of sublethal concentrations of antibiotics meant that it had slowly progressed to present as $\mathrm{CNE}$ several months later. In case 23 the association between $S$ bovis endocarditis and a large bowel neoplasm was $\operatorname{seen}^{27}$ with the original diagnostic clue being the positive antibody titre against $S$ bovis on immunoblotting.

The current management of CNE is based on the empiric use of either penicillin or ampicillin in combination with gentamicin. ${ }^{21}$ This regimen is effective against streptococci, some enterococci and most organisms in the HACEK group. Outcome has been correlated with response to this therapy. In 52 patients with $\mathrm{CNE}$ $92 \%$ of the patients who became afebrile after one week of antimicrobial therapy survived, compared with $50 \%$ of the patients who remained febrile after one week $(p<0.02) .{ }^{6} \mathrm{Im}$ munoblotting serum samples against extracts from the commonest streptococci and enterococci provides a way of making a positive diagnosis in a proportion of these cases.

Professor JP Burnie was in receipt of a grant from the British Heart Foundation and I Clark from the North West Regional Health Authority.

We thank the following for kindly providing clinical material: Drs Z Adhani, KD Allen, M Atkins, B Bannister, JG Barr, A Bouvet, J Brown, A Bure, I Cartmill, AK Chaudhauri, J Cohen A Galloway, I Gatt, AP Gibb, HT Green, JGM Hastings, MC Kelsey, C McCaughey, RG Mitchell, S Namnyak, O Driscoll B Oppenheim, G Philips, MM Rothburn, SA Sampson, MD Simmons, G Speirs, TN Standbridge, EL Teare, J Telford, DJ Warhorn, RJ Wiggins, and PJ Wilkinson.

1 McCarthy AC. Changing trends in infective endocarditis f Clin Pathol 1992;45:945-8.

2 James PA. Laboratory aspects of infective endocarditis. $B$ 7 Biomed Sci 1993;50:249-57.

3 Cannady PB Jr, Sanford JP. Negative blood cultures in infective endocarditis: a review. South Med f 1976;69: infective

4 Werner AS, Cobbs CG, Kaye D, Hook EW. Studies on the bacteremia of bacterial endocarditis. FAMA 1967;202: 199-203.

5 Pazin GJ, Saul S, Thompson ME. Blood culture positivity: suppression by outpatient antibiotic therapy in patients with bacterial endocarditis. Arch Intern Med 1982;142 263-8.

6 Pesanti EL, Smith IM. Infective endocarditis with negative blood cultures: an analysis of 52 cases. $A m \mathcal{F}$ Med 1979 66:43-50.

7 Von Reyn CF, Levy BS, Arbeit RD, Friedland G, Crumpacker CS. Infective endocarditis: an analysis based on strict case definitions. Ann Intern Med 1981;94:505-18.

8 Shanson DC, Hince D. An immunofluorescent method for detecting endocarditis antibodies against viridans streptococci in "Strep viridans" endocarditis. $f$ Clin Pathol tococci in "Strep

9 Shanson DC, Kirk N, Humphrey R. Clinical evaluation of fluorescent antibody test for the serological diagnosis of Streptococcal endocarditis. F Clin Pathol 1985;38:92-8.

10 van de Rijn MG, Bouvet A, Roberts RB. Enzyme-linked immunosorbent assay for the detection of antibodies to nutritionally variant streptococci in patients with endocarditis. F Infect Dis 1986;153:116-21.

11 Russell MW, Wu H-Y, White PL, Kilian M, Henrichsen J. Serum antibody responses to Streptococcus mutan antigens in humans systemically infected with oral strep tococci. Oral Microbiol Immunol 1992;7:321-5.

12 Kjerulf A, Tvede $M$, Hoiby $N$. Crossed immunoelectrophoresis used for bacteriological diagnosis in patients with endocarditis. APMIS 1993;101:746-52.

13 Aitchison EJ, Lambert PA, Smith EG, Farrell ID. Serodiagnosis of Streptococcus faecalis endocarditis by im- 
munoblotting of surface protein antigens. $\mathcal{f}$ Clin Microbiol 1987;25:211-15.

14 Burnie JP, Holland M, Matthews RC, Lee W. Role of immunblotting in the diagnosis of culture negative and

15 Clark I, Burnie JP. Immunoblotting and culture positive endocarditis. F Clin Pathol 1991;44:152-6.

16 Durack DT, Lukes AS, Bright DK. New criteria for diagnosis of infective endocarditis: utilization of specific echocardiogram findings. Am f Med 1994;96:200-9.

17 Brooks W. PhD Thesis. Manchester Univ; March 1994.

18 Rosen P, Armstrong D. Nonbacterial thrombotic endocarditis in patients with malignant neoplastic diseases. Am f Med 1973;54:23-9.

19 Brooks W, Burnie JP. Cloning and sequencing the endocarditis immunodominant antigen of Streptococcus sobrinus strain MUCOB 263. $¥$ Med Microbiol 1994;40: sobrinus

20 Beighton D, Hardie JM, Whiley RA. A scheme for the identification of viridans streptococci. $\mathcal{f}$ Med Microbiol identification of

21 Tunkel AR, Kaye D. Endocarditis with negative blood cultures. $N$ Engl $\mathcal{F}$ Med 1992;326:1215-17.
22 Burnie JP, Clark I. Diagnosing endocarditis with the cloned $112 \mathrm{kDa}$ antigen of Enterococcus faecalis. $\mathcal{F}$ Immunol Methods 1989;123:217-25.

23 Clark IM, Burnie JP. Isolation and sequence determination of an immundominant antigen from Enterococcus faecalis. Serodiagn Immunother Infect Dis 1993;5:85-92.

24 Crain MJ, Waltman DW, Turner JS, Yother J, Talkington DF, McDaniel LS, et al. Pneumococcal surface protein A (Psp A) is serologically highly variable and is expressed by all clinically important capsular serotypes of Streptococcus pneumoniae. Infect Immun 1990;10:3293-9.

25 Sussman JI, Baron EJ, Tenenbaum MJ, Kaplan MH, Greenspan J, Facklam RR, et al. Viridans streptococcal endocarditis: clinical microbiological, and echocardiographic correlations. F Infect Dis 1986;4:597-603.

26 Matthews RC, Burnie JP, Howat D, Rowland T, Walton F. Autoantibody to heat-shock protein 90 can mediate F. Autoantibody to heat-shock protein 90 can mediate protection against systemic candidosis. Immunology 1991;

27 Zarkin BA, Littlemoe KD, Cameron JL, Effron PN, Maggnison TH, Pitt HA. The triad of Streptococcus bovis bacteremia, colonic pathology and liver disease. Ann Surg
1990;211:786-92. 